\title{
Mitigating Effects of Climate Change and Deforestation on Bees With Respect to Their Ecology and Biology
}

\author{
Musiliyu Oladipupo Mustafa \\ Department of Forest Conservation and Protection \\ Forestry Research Institute Nigeria, P.M.B. 5054, Ibadan, Nigeria \\ Tel: 234-805-843-1622 E-mail: mustafamusiliyu@yahoo.com \\ Olubusola Temitope Adeoye (Corresponding Author) \\ Department of Forest Conservation and Protection \\ Forestry Research Institute Nigeria, P.M.B. 5054, Ibadan, Nigeria \\ Tel: 234-803-881-2193 E-mail: olubusolacrown@yahoo.com
}

Folorunso Ishaq Abdulalzeez

Department of Forest Conservation and Protection

Forestry Research Institute Nigeria, P.M.B. 5054, Ibadan, Nigeria

Tel: 234-3524-4028Ｅ-mail: ibnabdulazeezimam@gmail.com

Olukayode Dare Akinyemi

Department of Forest Conservation and Protection

Forestry Research Institute Nigeria, P.M.B. 5054, Ibadan, Nigeria

Tel: 234-703-826-2669Ｅ-mail: olukayodeakinyemi2007@yahoo.com

Received: June 15, 2015 Accepted: June 25, 2015 Published: October 22, 2015

doi:10.5296/jee.v6i2.8460ＵRL: http://dx.doi.org/10.5296/jee.v6i2.8460

\begin{abstract}
Deforestation occurs around the world; though tropical rainforests are particularly targeted, it
\end{abstract}




\section{Macrothink}

is considered to be one of the contributing factors to global climate change. While Nigeria is probably best known today for its oil deposits, according to the World Resources Institute, Nigeria is home to 4,715 different types of plant species, and over 550 species of breeding birds and mammals, making it one of the most ecologically vibrant places of the planet. It is also one of the most populous country with appalling deforestation record. This situation is hence making our ecosystems, biodiversity, agriculture and other natural endowments highly unsecured. The Forest provides excellent resources for bees and beekeeping, and bees are a vital part of forest ecosystems. Bees are essential for sustaining our environment because they

Pollinate flowering plants and conserves biological biodiversity along with their products (honey, propolis, bee wax, royal jelly and bee venom) which are beneficial to man. Conservation of the forest is therefore imperative for sustainable beekeeping. The study reviews the different causes of climate change and how they affect different natural forest activities which are weather-dependent. Also how climate change and other causes (both natural and man-made) lead to deforestation, which in turn distort sustainable honey production in Nigeria. Different sustainable measures hoped to alleviate the effects of climate change and deforestation where also discussed.

Keywords: Climate change, Deforestation, Apiculture, Biodiversity and agroforestry 


\section{Introduction}

Deforestation is a global phenomenon, which needs concerted attention; it leads to climate change in steps. As a result of these changes in climate parameters, our ecosystems, forest endowments and biodiversity in general, are prone to insecurity (Adeyemo and Akindele, 2008). Efforts made by the Kyoto protocol treaty of 1997 was a masterpiece for United Nations to objectively address issue of climate change by designing to assist countries in adapting to the adverse effects of climate change and facilitate development of various techniques in increasing resilience against impact of climate change, which would consequently lead to food insecurity.

Food security is distorted by inclement weather because it is rainfall pattern dependent; the evidence was the fact that unpredictable change in the onset of rain during the yesteryears led to smothering of crops, the situation which was linked with unpredictability of the agriculturally important August dry spell (Odofin et al., 2007). This situation is in consonance with Nigerian Environmental study and Actions report that effects of climate change include poor nutrition, low agricultural yields, poverty and proliferation of disease vectors and pests. Climate change disturbs the natural balance in forest on which honey bees depend for honey production.

The forest is a complex ecosystem and a highly dynamic array of living communities of plants and animals interacting with both living and non-living things in the soil. The system is self-renewing and transforming (succession) through a cycle of processes. Meanwhile, human interference has many influences on the ecosystem (Badejo et al., 2009). Forests maintain the biological diversity, hydrological cycles, and absorption of green house gases and supporting agriculture are some of the unsung benefits of good forest management. Honey product depends largely on areas where bees can get the necessary nectar, water and labor to protect their hives.

Nigeria is a large country with an area of $923,768 \mathrm{Km}^{2}$, and a population above 120 million. The country is blessed with a tropical climate with a variety of vegetation from mangrove in the south through forest in the West and East to savanna in the North, making availability of food and crops year round possible (NEST, 1992). Nigerian forests harbor and serve as natural home for the bees. Bee keeping is an ancient art that is yet to be fully utilized in Nigeria. Even though there is no solid statistics on production level, we are highly convinced that is underutilized (Adegbola et al., 1998). Forest fruit trees and some other tree species contribute to bee production, unfortunately over exploitation of trees through ring barking or girding, complete girding, felling for complete bark removal and inadequate regeneration time has led to death of most tree species. According to the United Nations Food and Agriculture Organization, Nigeria cleared an average of nearly 410,000 hectares of forest from 1990 to 2005 which translates into nearly four percent of the country's rainforests disappearing every year. A considerable part of Nigeria forest is being destroyed through indiscriminate and reckless logging of timber, extraction of Non- Timber Forests Products (NTFPs) and log transportation of timber. During these activities, wild animals are killed and their habitats destroyed, thereby altering their feeding and grazing pattern (Badejo et al., 
2009)

Forest fruit trees and some other tree species contribute to bee production, unfortunately over exploitation of trees through ring barking or girding, complete girding, felling for complete bark removal and inadequate regeneration time has led to death of most tree species. A considerable part of Nigeria forest is being destroyed through indiscriminate and reckless logging of timber, extraction of Non- Timber Forests Products (NTFPs) and log transportation of timber. During these activities, wild animals are killed and their habitats destroyed, thereby altering their feeding and grazing pattern (Badejo et al., 2009). Conservation and forest related policies have failed to reduce forest decline in Nigeria: the weakness of conservation and sustainable forest management effort is due to poor governance, lack of political will, lack of clear land tenure and land-use rights, lack of adequate valuation of forest biodiversity, lack of appropriate local economic and global policies, inestimable and poor financial or human recourses in environmentally sound technology (Badejo et al., 2009)

This paper identified factors responsible for climate change and deforestation and how these two circumstances both affect honey production and abundance. Probable solution to alleviate the painful effects of consequences of climate change and deforestation on honey quantity and quality are also suggested for sustainable environment management and yields.

\subsection{Concept and Factors Responsible for Climate Change}

Climate change over any particular place around the world is caused by a host of interacting factors both natural and man-made. Okali, (2007) defined climate change as a deviation from the normal climatic conditions of an area due to land-atmosphere, land ocean and ocean-atmosphere interactions and which cause alterations in balance of gases in the atmosphere. The gases are otherwise called radioactive forcing factors and are responsible for global warming and climate change. They include green house gases of carbon dioxide, nitrous oxide, methane and halocarbons. They also include aerosols which are negative forcing values producing cooling effects in atmosphere and solar activities with volcanic eruptions. These reduce ozone layer factors and manifest themselves as rising temperature, irregular humidity and rainfall patterns flooding, erosion of coastal plains, rising sea levels, drought, desertification, threat to natural water resources and increase in land erosion (Aluko, 2008).

The ozone layer that had shielded the earth from devastating ultraviolet radiation since life began is now diminishing because of the use humans have made over 65 years now of ozone layer depleting substances particularly CFCs and halons. Agnew and Fennessy, (2001) reported that ozone layer forms a layer in the stratosphere from 10 to $50 \mathrm{~km}$ above the earth surface and acts like a giant sun shade protecting plants and animals from the sun's harmful ultraviolet radiation. Also ozone filters $70 \%$ of less damaging portion of ultraviolet radiation out to the earth. Radiation at this wavelength is responsible for sunburn, skin cancers and genetic structure damage in plant and animals. Ozone layer depletion may pose threat to both plants and animals making them to grow more slowly while some could be stunted, yield from crop may also fall and forest may be damaged. The industrialized world contributes more to ozone-layer depletion than the developing countries through the development, of 
CFCs and other chemicals. They hence have the responsibility to financial and technological help to these countries and help them to improve living standards of their people without the older, polluting technology that destroy ozone (UNEP, 2002).

Apart from acting as ultraviolet radiation filter, ozone layer an important role in regulating the earth temperature because absorption of ultraviolet radiation leads to increase in environment temperature: change in ozone layer at any height can therefore influence the earth climate, and lead to climate change with its attendant effect on environment (Odeyemi et al., 2001).

\subsection{Climate Change and Its Link with Deforestation}

Climate is the average weather condition over an area for a period of time not less than 30 years (Onuigbo, 2004). The totality of well-being of man and other living organisms is greatly influenced by climate; areas with extremity of climate (either hotness or coldness) are inhabited by scanty population of living organisms. Also primary production which is the exclusive responsibility of green plants is the principal source of needs of man for food, medicine, shelter and various raw materials for industries (Olajide et al., 2008). The tropical rainforest has been adjusted as the most biologically diverse ecosystem (Turner, 2001). Regrettably the tropical rainforest has been widely decimated through indiscriminate exploitation for timber and agricultural activities. It has been estimated that about 14.6 million hectares is destroyed yearly (FAO, 2000).

Consequences of destroying tropical rainforest on climate and physical environment are global warming, decrease in rainfall, water source losses. Erosion and desertification, genetic loss and loss of natural heritage (Oladeji et al., 2008). Deforestation is the conversion of forested areas to non- forest land for use as arable land pastures, urban use, logged area or waste land. It is removal of forest cover to an extent that allows for alternative use, it is also the removal of forest cover naturally or by human activities it may occur abruptly when the forest is cleared for agriculture production or make gradually as a result of unsustainable logging practices (Otegbeye and Oyeanusi, 2006). Generally, the removal or destruction of significant areas of forest cover has resulted in a degraded environment with reduce biodiversity. The world's forest is disappearing at alarming rate: about 10,000 years ago, before the dawn of agriculture, forests and open woodland covered about 15.3 billion acres 96.2 billion ha. Over the centuries about one-third of these natural forests have disappeared: 11.3 ha of tropical forests are cut each year. Between 1985 and 1990, 85 million ha of tropical forest had been cut or cleared for other purposes (Williams, 2003).

In Nigeria, large areas of natural forests are being exploited for tree species such as Khaya grandifolia (mahoganies), Nauclea diderrichii (Opepe), Terminalia ivoriensis (Idigbo), Terminalia uperb (Afara). Triplochyton scleroxylon (Obeche) and other known species in international market. High intensity of logging and illegal exploitation of these tree species and others has continued to pose serious threats to the country's forest resources (Adekunle and Akinlemibola, 2008). Other causes of deforestation are fire and clearing for agriculture, fuel wood cutting, old shifting cultivation and slash and burn method of agriculture (Salami, 2006) 
Nigeria has the world's highest deforestation rate of primary forest and has lost more than half the primary forest in the last five years; causes are logging, subsistence agriculture and fuel wood collection (because there is growing demand for wood for fire), construction, paper and furniture making as well as clearing of land for commercial and industrial development (Ekenade and salami 1995). Other reasons include illiteracy and ignorance of the local people that believe forest is a free gift of nature and cannot be exhausted; hence they harvest from forests indiscriminately. Impacts of deforestation are soil erosion, drought, desertification, landslides, biodiversity loss, water cycle devastation, health and disease spread and pollution (Adekunle and Akinlemibola 2008).

To support this assertion, the weather records in Ibadan revealed almost steady decline in rainfall and increase in both minimum and maximum temperatures; this observation is an epitome of drought and water cycle devastation within 37 years.

Table 1. Agrometerological weather Data Between 1970 And 2007 at Forestry Research Institute of Nigeria (FRIN) Headquarters, Jericho, Ibadan

\begin{tabular}{lllll} 
Years & Rainfall $(\mathbf{m m})$ & No of rainy days) & Max Temp.(0c) & Min Temp.(0c) \\
\hline $1970-1979$ & 1444.0 & 92 & 26.9 & 21.6 \\
$1979-1989$ & 1408.0 & 86 & 31.6 & 23.4 \\
$1990-1999$ & 1373.0 & 100 & 32.7 & 23.6 \\
$2000-2001$ & 1178.4 & 72 & 32.7 & 23.7 \\
$2001-2002$ & 1133.6 & 54 & 32.9 & 23.3 \\
$2002-2003$ & 1196.4 & 73 & 32.8 & 23.9 \\
$2003-2004$ & 1304.0 & 79 & 32.5 & 23.3 \\
$2004-2005$ & 1006.6 & 62 & 32.4 & 24.2 \\
$2005-2006$ & 1314.0 & 62 & 30.5 & 25.5 \\
$2006-2007$ & 1198.5 & 56 & 32.5 & 23.7 \\
\hline
\end{tabular}

Source: FRIN, Ibadan.

\section{Honey Biology and Its Sustainable Production}

Honey is produced when honey bees (Apis mellifera) suck nectar, sweet juice and pollens from different plant species available; composition of honey therefore varies according to the source of the nectar. This may explain why honey contains many different substances important in human nutrition such as proteins, carbohydrates, organic acids, hormones, antibiotic elements and small quantity of unknown substance (Brown, 1993). Honey is hence a forest product, this means that its quality and quantity depend much on forest vegetative and floral viability. 


\section{Macrothink}

Mustsaens, (1991) reported that the main nectar flow in Ibadan area is from July to February with a peak in January when large forest trees such as Bombax buonopozense or silk cotton tree (Obokha in Benin, Akpu in Igbo and Pompola in Yoruba), Hilderardia barteri (Kariya in Hausa, Eso okurugbedu shishi in Yoruba, Ufuku in Yoruba), and Berlina grandiflora (Podo in Yoruba, Ekpagari in Edo) and Albizia glaberrima (Ayinreta in Yoruba) are in flowers. Based on utter dependence of apiculture on forest flowers and high rate of deforestation, there is the dilemma of beekeepers concerning the effects of logging on nectar production in the forest (Law and Chidel, 2007). Apart from logging, annual fire is a serious threat to several plant species for honey production and its sustainability.

Some multipurpose and melliferous flora in Okuku, Osun State in Nigeria are listed in (Table 2). Okuku is located in southern Guinea Savanna zone where the woody/shrubby/grassy vegetation is always completely burnt twice annually during the dry season period lasting for five months (between November and March); this situation could imply low quality and quantity of honey in the locality.

Table 2 . Some multipurpose trees and melliferous flora of Okuku, Nigeria.

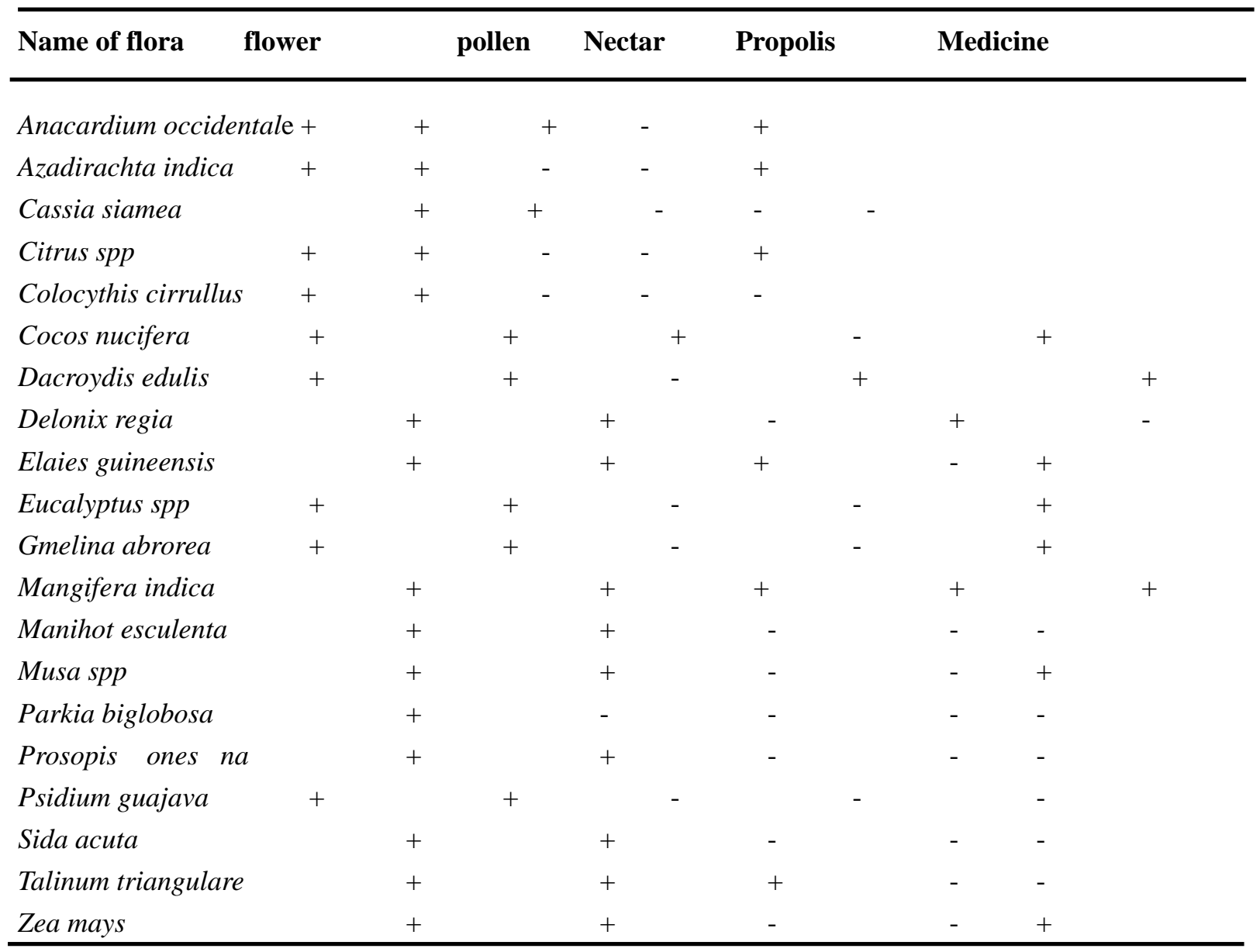

Source Badejo et al ., (2003) 
Agro-apiculture according to Adekola et al.,2006) means domestication of bees for the purpose of honey production and utilization of the other hive products such as bee wax propolis, bee venom and pollens for the benefits of mankind. It is also management and maintenance of colonies of honey bees in their natural home for honey inside tree hollow, log or cave but humans have transported some of them home for domestication. Products of beekeeping are honey, bees wax, propolis, bee venom, royal jelly and pollen. Honey is used for tobacco products especially cigarettes to keep it moist, in breadmaking as substitute for refined sugar, treatment of gastrointestinal ailments, surgical wounds and bad sores (Adekola et al., 2006).

FAO statistical data indicated that in 2004 estimated world honey and bees wax production was 1.38 million metric ones (MT) and bees wax production 60.153MT In comparison to these amounts, production in sub-saharan Africa was 135,373MT of honey and 14,165 mt of bees wax most of which came from a very few countries. Table below shows the quantity of honey and bee wax produced by selected African countries(Adekolaet al., 2006).

Table 3. Production of honey and bees wax (metric tones) in selected African countries.

Country

Bees

\begin{tabular}{lll} 
& Honey & Wax \\
\hline Angola & 23,000 & 2,300 \\
Burundi & 240 & 45 \\
Cameroun & 3,000 & 287 \\
Central African Rep. & 13,000 & 690 \\
Chad & 960 & 0 \\
Ethiopia & 39,000 & 4,300 \\
Guinea & 600 & 0 \\
Guinea Bissau & 65 & 100 \\
Kenya & 21,500 & 2,490 \\
Madagascar & 3,930 & 390 \\
Mali & 300 & 60 \\
Mozambique & 390 & 65 \\
Rwanda & 30 & 21 \\
Reunion & 100 & 0 \\
Senegal & 550 & 77 \\
Sierra Leone & 500 & 110 \\
Sudan & 710 & 175 \\
Tanzania & 27,000 & 1,830 \\
Uganda & 300 & 1,200 \\
Zambia & 200 & 2 \\
\hline
\end{tabular}

Source: Wilson, 2006. 
From the above table it is evident that Africa production represents just $9.8 \%$ of the world's production of honey and $23 \%$ of the world's bees wax production (Adekola et al., 2006). The way forward to generate sustainable honey production is conservation and environmental conservation awareness. Ayodele and Lameed (1999) listed conservation strategies as

- Improvement on policies and laws in biodiversity in Nigeria on habitat protection.

- Tropical forestry action plan for biodiversity production.

- Enhancing National Policy on environment.

- ICRAF also reported six global research projects which are fundamental to agroforestry science. They include the following:

- Maximum on- farm productivity of trees and agroforestry systems.

- Improving tree product marketing for small holders.

- Targeting agroforestry intervention to enhance land productivity and food health

- Developing policies and incentives for multifunctional landscapes with trees that provide environmental services.

\section{Effects of Deforestation on Bees}

Man has been the greatest enemies of honey bee. Man has considerably reduced natural vegetation through deforestation. Dry season bush burning considerably reduce wild bee population. The use of insecticides by man in an attempt to control pest often poison pollen and nectar that bees carry to their hives. Floral diversity within the flight range of a honey bee colony is of utmost importance for the output of bee keeping (Adekola et al., 2006). The most serious problem to indigenous bees in Nigeria is deforestation. The bee in West Africa (Apis mellifera) is very aggressive, difficult to manage and has an unusual propensity to abscond. Loss of biodiversity ultimately leads to loss of support for its maintenance. Another problem arising from deforestation is unfavorable weather condition emanating from habitat destruction (because their natural habitat is a hollow- tree, log or cave), causing inability of flowers to secrete enough nectar for bees to transform it into honey (Adegbola et al., 1998).

Insect pests, found in all parts of Nigeria, are the greater wax moth Galleria mellonella and the lesser wax moth Achroia grisella (Lepidoptera:pyrallidae) Deathshead hawkmoth Acherontia atropos (Lepidoptera: sphingidae), and the commonest pest, the small hive beetle Aethina sp. (Coleoptera: Nitidulidae). Was most recorded for the forest zone of Southern Nigeria ( Mutsaers, 199a) along with the large hive beetles Oplostomus hoplostomus fuligineus, Rhizoplatys bituber calaths, Goniochilus bicolor and Diplognata gagates (coleopteran: scrarabaeidae), bee house Braula coeca (Diptera: Brauilidae) a wingless fly (smith, 1960; Jesseni 1967). However, the large hive beetles and the bee house are common in Northern Nigeria (Jessen, 1967).

Other enemies are ants, snakes, lizards, bee-eating birds, mice and honey badger. Termites may also cause problems by damaging the beehives. No records have been made in Nigeria 
for diseases of honey bees.

\section{Conclusion and Recommendation}

It is a big task to motivate people to protect trees and forest because of contradiction existing between conservation and exploration of trees for fuel construction and other numerous benefits. Therefore no single group of producers or any income opportunity from the forest is too small to be neglected (Sevension, 1999). It is a collective responsibility of all forest users and managers. Popular protection campaigns like the Chipko Movement in India should be emulated: based on the following methods conservation could be improved upon:

1. Protection of existing trees and forest

2. Planting new trees according to local needs

3. Placing emphasis on community forestry

4. The use of locally-suited trees

5. Use of fast multipurpose trees

6. Use of fast growing species

7. Strive for floral diversity

8. Wildlife conservation using different mass media extension strategies

9. Education and training of industrialists against indiscriminate release of pollutants into environment.

10. Promotion of controlled bush burning, controlled application of pesticides and herbicides by farmers beekeepers by NGOs.

11. Embarking on homogenous honey production as being done in Forestry Research Institute, Ibadan where Thevetia peruviana Steud plantation is being used for comparative honey research.

\section{References}

Adegbola, P. O., Ashiru, M. O., \& Alebiosu, 1. B. (1998). Apriculture and underutilized Forest Resources: paper present at the Workshop on Agroforestry and Land Management Practices, Abeokuta, Ogun State Nigeria Nov.10th 1998.

Adekola, P. J., Ojo, M. O., Samuel, A. A., Aruwayo, A., \& Aderounmu. A. F. (2006). Apiculture in Nigeria, A viable source of livelihood. Journal of Forestry Research and Management, 3, 59-67.

Adekunle, V. A. J., \& Akinlemibola, O. (2008). Effects of Deforestation on climate change and Global Warning in Nigeria. In proceedings of 32nd Annual conference of Forestry Association of Nigeria (FAN), Umuahia, Abia state. In Popoola, L. (Ed). 20th-24th October 2008. 171-182. 
Adeyemo, T. O., \& Akindele, S. O. (2008). ClimateChange and National Security. In Proceedings of the 32th annual Conference of Forestry Association of Nigeria. Umuahia Abia State. Popoola L. (ed) 23.

Agnew, C., \& Fennessy. S. (2001). Climate Change and Nature conservation:Managing the physical Environment. New York. 273.

Aluko, A. P. (2008). Implication of Climate change on sustainable forest Management and climate change in Nigeria at Bisrod Furniture Company, Ijebu Ode, Ogun State.

Ayodele, I. A., \& Lameed, G. A. (1999). Essentials of Biodiversity Management. Powerhouse press and publishers Ibadan, 57-74.

Badejo, S. O. O., Ekpo, E. N. \& Oyelowo, O. J. (2009). Implication of Deforestation on common African Bees in Nigeria. Paper submitted at the International Conference on the Dark Bees, Our Hope for the Future. Scotland, U.K.7th -9th September. 2009.

Browns, Royden (1993). Bees Hives Product Bible. Avery Publishing Group Inc, N.Y.226.

Ekenade, O., \& Salami, A. T. (1995). Innovation and Diffusion in farm Management: a Case study of the impact of the Oyo State Agriculture Development Project on Peasant Farming in Nigeria, Ife Social Science Review, 12(1\&2), 1-7.

Food and Agricultural Organisation (FAO) (2000). Rome paper 140.

Hill, M. (2000). The Management and Maintenance of colonies in honey bee science and Technology Encyclopaedia http;// www. answer .com/topic / beekeeping.

International Conference on Research on Agroforestry (ICRAF) (2001): Shifting Cultivation Toward, sustainable and Resource conservation in Asia. 421.

Law, B., \& Chidel, M. (2007). Effect of logging on Nectar-producing Eucalyptus: Electronic Journal of Rural Industries Research and Development Corporation Publication Number 07/138. Project number SFNZA 1.

Mutsaens, M. (1991). Bees in Southern Nigeria. The Nigeria Field, 56-3-18.

Nest (Meaning of NEST?). (1992). the Challenge of Development in Nigeria: An NGO Report for the United Nation Conference on Environment and Development, Rio de Janeiro, Brazil, 1-12.

Odofin, B. T., Halidu, S. K., \& Akinyemi, O. D. (2007). Implication of Weather and Climate on Sustainable Agriculture in Rainforest zone of Nigerian in Proceeding of International Conference of Nigeria Meteorological Society held at Federal University of Technology. Akure, 11th-15th November 2007, 37-40.

Okali, D. U. U. (2007). Climate Change and Sustainable Development: Challenge to Nigeria paper presented at 38th International Disciplinary Research Discourse. Postgraduate school. University of Ibadan.

Olajide, O., Udofia, S. I., \& Etigade, E. B. (2008). Consequence of Rainforest's Destruction 
on climate and physical Environment. In proceeding of 32nd annual Conference of Forestry Association of Nigeria. In Popoola, L. (Ed). Umuahia. Abia State 20th-24th October, 2008. 75-79.

Onuibgo. I. C. (2004): Population pressure and Climate Change: realities and dangers. In Ibitoye, O, A. (Ed), population. Environment and Sustainable Development in Nigeria Pp188, 121.

Otegbeye, G. O., \& Oyeanusi, A. E. (2006). The Impact of Deforestation on soil Erosion and on the Socio-economic life of Nigeria. In Lybijano, Sustainable Environment and R. U Okechuku (ed): 2006. Sustainable Environmental Management in Nigeria. Mattivi Publications, Ibadan. 12. 5pp.

Salami, A. T. (2006). Monitoring Deforestaton and Implication for Biodiversity Loss in Nigeria using Data from Nigeria SAT-1 and other satellites. A Report Submitted to National Space Research and Development Agency (NASRDA) Federal Ministry of Science and Technology, Abuja.

Sevension. B. (1991). Bees and Trees. Working paper No. 83 Uppsala. 80pp.

Turner. I.M. (2001). The Ecology of Trees in Tropical Rainforest.Cambridge University Press. Cambridge. pp298.

UNEP. Report (1992). The Impact of Ozone-layer Depletion. SCBD. England. 55.

Williams, M. (2003). Deforesting The Earth, University of Chicago. ISBN 0-22689926. $198 \mathrm{pp}$.

Wilson, R. T. (2006). Current Status and Possibilities for Improvement of Tradition Apriculture in Sub-saharan African. Livestock Research for Rural Development 18, 1-11.

\section{Copyright Disclaimer}

Copyright for this article is retained by the author(s), with first publication rights granted to the journal.

This is an open-access article distributed under the terms and conditions of the Creative Commons Attribution license (http://creativecommons.org/licenses/by/3.0/). 